\title{
Moraxella boevrei sp. nov., a New Moraxella Species Found in Goats ANGELI KODJO, ${ }^{1 *}$ YVES RICHARD, ${ }^{1}$ AND TONE TØNJUM ${ }^{2}$ \\ Ecole Nationale Vétérinaire de Lyon, F-69280 Marcy l'Etoile, France, ${ }^{1}$ and Institute of Microbiology, Rikshospitalet (National Hospital), N-0027 Oslo, Norway ${ }^{2}$
}

\begin{abstract}
Six Moraxella-like strains that formed a phenotypically homogeneous group were isolated from the nasal flora of healthy goats. Total genomic DNA-DNA hybridization, rRNA gene restriction pattern, DNA base composition, and genetic transformation studies were performed to determine the relationships of these bacteria to species belonging to the genus Moraxella and other fastidious gram-negative species. The new group of isolates was very homogeneous, as shown by rRNA gene restriction fragment length patterns (ribotyping), and these organisms displayed high relative binding ratios (RBRs) to each other in DNA-DNA hybridization experiments (RBRs, $\geq 58 \%$ ) but distinctly lower levels of DNA homology with all other species investigated. However, the RBRs obtained with species of the genus Moraxella were higher than the RBRs obtained with all other gram-negative strains examined. Although the new strains had most of the Moraxella bovis phenotypic characteristics except nitrate reduction, quantitative and qualitative genetic transformation data led to the conclusion that they belong to a distinct new cluster in the genus Moraxella. The results of this study, combined with the general morphological and phenotypic profiles of the new strains, are consistent with the creation of a new Moraxella species, for which the name Moraxella boevrei is proposed. Strain $88365(=\mathrm{ATCC} 700022=$ CCUG $35435=$ NCTC $12925=$ CIP 104716) is the type strain of M. boevrei.
\end{abstract}

Moraxella bovis is the bacterial agent involved in acute and chronic cases of infectious bovine keratoconjunctivitis or pinkeye, a contagious disease of cattle (5). Investigators have reported that the number of $M$. bovis isolations from bovine upper respiratory tracts increases during summer months (10), and recovering the bacteria from cattle during cold seasons (i. e., autumn and winter) has proven to be difficult (2). These observations suggested that there are carriers of $M$. bovis in other animals (3). Other investigators have reported the isolation of bacteria resembling $M$. bovis from various animals, including horses $(8,13-15)$, sheep $(20-22,33)$, and goats $(23$, 25).

It has now been demonstrated that the characteristics of the equine Moraxella isolates (formerly Moraxella equi) are compatible with the description of a nonhemolytic variant of $M$. bovis, a member of the Moraxella lacunata group or the classical moraxellae. This group includes M. lacunata, M. bovis, Moraxella nonliquefaciens, and Moraxella caprae ( $M$. caprae is a new species recently isolated from goats [23]). Many other strains isolated from sheep or goats or from other mammals have not been precisely identified because of a lack of adequate characteristics for distinction. Identification of these organisms to the species level by cultural and conventional biochemical techniques in clinical laboratories has proven to be difficult. Serum liquefaction, nitrate reduction, and hemolysis on blood agar are the main traits that can be used to differentiate the species of the classical moraxellae $(27,31)$. However, it has been demonstrated that most Moraxella strains can be identified by genetic transformation with nutritional auxotrophic mutants (17-19) or by genetic transformation of the high-level streptomycin resistance marker $(4,5)$. Ratios of interstrain transformation to intrastrain transformation close to 1.0 for members of individual species have been demonstrated in this genus $(7,12,29,31)$. The transformation ratio usually ranges from $10^{-1}$ to $10^{-3}$ from one species to another within

\footnotetext{
* Corresponding author. Mailing address: Ecole Nationale Vétérinaire de Lyon, BP83, 1 Avenue Bourgelat, F69280 Marcy l'Etoile, France. Phone: 3304788725 91. Fax: 3304788725 94. Electronic mail address: kodjo@univ-lyon1.fr.
}

the classical moraxellae $(4,5)$. The species may also be identified by total genomic DNA-DNA hybridization experiments, in which members of one species usually exhibit relative binding ratios (RBRs) close to $70 \%$ or higher $(29,31)$.

Recently, we isolated from the upper respiratory tracts of healthy goats from the same herd six hemolytic Moraxella strains resembling $M$. bovis $(21,22)$. The strains had all of the conventional biochemical and enzymatic features of collection strains of $M$. bovis except one; they were all capable of nitrate reduction. These properties suggested that these isolates belong to $M$. bovis, but the sodium dodecyl sulfate (SDS)-polyacrylamide gel electrophoresis of whole-cell protein profiles placed them in a group different from the group containing the classical $M$. bovis reference strains (22). These strains also transformed $M$. bovis only weakly in qualitative genetic transformation assays (21).

In the present study, the relationships of the six hemolytic goat strains to all members of the genus Moraxella were investigated by performing quantitative genetic transformation, total DNA-DNA hybridization, rRNA gene restriction pattern (ribotyping), and DNA base composition analyses.

\section{MATERIALS AND METHODS}

Bacterial strains and growth conditions. The strains investigated, including the strains of various Moraxella species and other fastidious gram-negative bacteria used for comparison, are listed in Table 1 . Strains were grown on $5 \%$ human blood agar plates (Difco) and chocolate agar plates incubated at $35^{\circ} \mathrm{C}$ in the presence of $5 \% \mathrm{CO}_{2}$.

Quantitative and semiquantitative genetic transformation assays. The media and reagents used have been described previously $(4,5)$. Spontaneous mutants for high-level streptomycin resistance were selected. DNAs were extracted from the mutants, and the DNA concentrations were adjusted to $200 \mu \mathrm{g} / \mathrm{ml}$. The quantitative transformation assay was performed by exposing $0.5 \mathrm{ml}$ of a recipient suspension to $0.05 \mathrm{ml}$ of each DNA for $20 \mathrm{~min}$. After DNase treatment, $0.1-\mathrm{ml}$ aliquots of each final suspension and appropriate dilutions were inoculated onto blood agar plates. The DNase treatment step was omitted from semiquantitative assays. The plates were preincubated for $7 \mathrm{~h}$ before they were placed on top of an agar layer, and the final concentration of streptomycin was $50 \mu \mathrm{g} / \mathrm{ml}$ after diffusion. The plates were incubated for an additional 3 to 5 days before colonies were counted and ratios of interstrain transformation to intrastrain (autologous) transformation were calculated $(4,5)$.

DNA-DNA hybridization. (i) DNA dot blot. DNA was extracted and blotted for use in dot blot hybridization experiments essentially as previously described ( 23 , 
TABLE 1. Bacterial strains used in this study

\begin{tabular}{|c|c|c|c|c|}
\hline Species & Strain $(\mathrm{s})^{a}$ & Other designation $(\mathrm{s})^{a}$ & Source (year) & $\begin{array}{l}\text { Reference(s) } \\
\text { or sender }\end{array}$ \\
\hline \multirow[t]{2}{*}{ Moraxella boevrei sp. nov. } & $88365^{\mathrm{T}}$ & $\begin{array}{l}\text { ATCC } 700022^{\mathrm{T}}, \text { CCUG } 35435^{\mathrm{T}}, \\
\text { NCTC } 12925^{\mathrm{T}}\end{array}$ & Goat nasal swabs (1988) & 23 \\
\hline & $\begin{array}{l}88363 \mathrm{~A}, 88363 \mathrm{~B}, 88364 \\
\quad 88365,88369\end{array}$ & & Goat nasal swabs (1988) & 23 \\
\hline \multirow[t]{2}{*}{ M. caprae } & NCTC $12877^{\mathrm{T}}$ & CCUG $33296^{\mathrm{T}}$, ATCC $700019^{\mathrm{T}}$ & Goat nasal swabs (1988) & 23 \\
\hline & $88100,88103,88104,88105$ & & Goat nasal swabs (1988) & 23 \\
\hline \multirow[t]{6}{*}{ M. bovis } & $\begin{array}{l}\text { ATCC } 10900^{\mathrm{T}} \\
\text { ATCC } 17948\end{array}$ & & Cattle pinkeye & 4,29 \\
\hline & CIP 649 & ATCC 17947 & Cattle pinkeye & CIP \\
\hline & 9 & & Cattle & 29 \\
\hline & $\begin{array}{l}\text { NCTC } 11012^{\mathrm{T}} \text { (also called } \\
\text { M. equi) }\end{array}$ & ATCC $25576^{\mathrm{T}}$ & Eye of horse & 29 \\
\hline & PG 500 & & Cattle IBK $^{b}$ & Field isolate \\
\hline & PG 501 & & Cattle IBK & Field isolate \\
\hline \multirow[t]{3}{*}{ M. lacunata } & ATCC $17967^{\mathrm{T}}$ & NCTC $11011^{\mathrm{T}}$ & Human conjunctivitis & ATCC \\
\hline & A947 & & Human conjunctivitis & 4,29 \\
\hline & 50136 & & Human conjunctivitis & 29 \\
\hline M. nonliquefaciens & ATCC $19975^{\mathrm{T}}$ & & Human nasal swab & $1,4,29$ \\
\hline M. osloensis & $\begin{array}{l}\text { CIP } 6835^{\mathrm{T}} \\
5873\end{array}$ & ATCC $20776^{\mathrm{T}}$ & Human spinal fluid & $\begin{array}{l}\text { CIP } \\
29\end{array}$ \\
\hline M. atlantae & CIP $8225^{\mathrm{T}}$ & ATCC $29525^{\mathrm{T}}$ & Human blood & CIP \\
\hline M. phenylpyruvica & CIP $8227^{\mathrm{T}}$ & ATCC $23333^{\mathrm{T}}$ & Human blood & CIP \\
\hline M. lincolnii & CCUG $9405^{\mathrm{T}}$ & & Human nasopharynx & 34 \\
\hline $\begin{array}{l}\text { Moraxella (Branhamella) } \\
\text { catarrhalis }\end{array}$ & $\mathrm{Ne} 11^{\mathrm{T}}$ & ATCC $23238^{\mathrm{T}}$ & Unknown & 31 \\
\hline M. (B.) ovis & $199 / 55^{\mathrm{T}}$ & ATCC $33078^{\mathrm{T}}$ & Ovine keratconjunctivitis & 31 \\
\hline$M .(B$,$) caviae$ & ATCC $14659^{\mathrm{T}}$ & CIP $7319^{\mathrm{T}}$ & Guinea pig pharynx & 23 \\
\hline M. (B.) cuniculi & ATCC $14688^{\mathrm{T}}$ & CIP $7317^{\mathrm{T}}$ & Rabbit oral mucosa & 23 \\
\hline Kingella kingae & $4177 / 66^{\mathrm{T}}$ & ATCC $23330^{\mathrm{T}}$ & Human nose & 31 \\
\hline K. denitrificans & NCTC $10995^{\mathrm{T}}$ & & & 31 \\
\hline Neisseria elongata & $6171 / 75$ & & & 31 \\
\hline $\begin{array}{l}\text { N. weaveri (formerly } \\
\text { CDC group M5) }\end{array}$ & B5522 & & & 1 \\
\hline Eikenella corrodens & ATCC $23834^{\mathrm{T}}$ & NCTC $10596^{\mathrm{T}}$ & Sputum & 31 \\
\hline Psychrobacter immobilis & NCMB 98 & CCUG 9702 & Gills of lemon sole & 23 \\
\hline Oligella urethralis & ATCC $17960^{\mathrm{T}}$ & & Human ear & 29 \\
\hline Haemophilus aphrophilus & $9574 / 86$ & & Sinusitis & 30 \\
\hline H. paraphrophilus & NCTC $10557^{\mathrm{T}}$ & ATCC $29241^{\mathrm{T}}$ & Paronychia & 30 \\
\hline Pasteurella multocida & 646 & & Pig & 30 \\
\hline P. haemolytica & NVI (serotype 1) & & & 30 \\
\hline Escherichia coli & $\mathrm{K}-12$ & & & 31 \\
\hline
\end{tabular}

${ }^{a}$ ATCC, American Type Culture Collection, Rockville, Md.; CIP, Collection Institut Pasteur, Paris, France; CCUG, Culture Collection, University of Göteborg, Göteborg, Sweden; NCTC, National Collection of Type Cultures, London, United Kingdom; NCMB, National Collection of Marine Bacteria, Aberdeen, Scotland.

'IBK, infectious bovine keratoconjunctivitis.

31). Briefly, DNA extracted by a modification of the method of Marmur (24) was heat denatured at $95^{\circ} \mathrm{C}$ for $10 \mathrm{~min}$, cooled on ice, and mixed with an equal volume of cold $2 \mathrm{M}$ ammonium acetate. DNA was applied to nitrocellulose filters by using a Hybri-Dot system (Bethesda Research Laboratories). Eight parallel dots

(1 $\mu \mathrm{g}$ each) and a Tris-EDTA buffer control were blotted for each strain. The filters were washed in $6 \times \mathrm{SSC}$ buffer $(1 \times \mathrm{SSC}$ is $0.15 \mathrm{M} \mathrm{NaCl}$ plus $0.015 \mathrm{M}$ sodium citrate) and then soaked in $2 \times$ Denhardts' solution for $1 \mathrm{~h}$ before they were baked in a vacuum oven at $80^{\circ} \mathrm{C}$ for $2 \mathrm{~h}$. Filters were stored dry until they were used (ii) Labelling of probes. Mechanically fragmented genomic DNA probes were labelled with $\left[{ }^{32} \mathrm{P}\right]-\mathrm{dCTP}$ to a specific activity of approximately $1 \times 10^{7} \mathrm{cpm} / \mu \mathrm{g}$

TABLE 2. DNA base compositions and affinities of $M$. boevrei strains to other Moraxella species as determined by genetic transformation

\begin{tabular}{|c|c|c|c|c|c|c|}
\hline \multirow[b]{2}{*}{ DNA donor } & \multirow{2}{*}{$\begin{array}{c}\mathrm{G}+\mathrm{C} \text { content } \\
(\mathrm{mol} \%)^{a}\end{array}$} & \multicolumn{5}{|c|}{ Ratios of interstrain transformation to intrastrain transformation with the following recipients: } \\
\hline & & $\begin{array}{c}\text { M. boevrei } \\
88365^{\mathbf{T}}\end{array}$ & $\begin{array}{c}\text { M. bovis ATCC } \\
10900^{\mathrm{T}}\end{array}$ & $\begin{array}{l}\text { M. lacunata } \\
\text { A947 }\end{array}$ & $\begin{array}{l}\text { M. atlantae } \\
\text { A1922 }\end{array}$ & $\begin{array}{l}\text { M. (B.) catarrhalis } \\
\mathrm{Ne}^{\mathrm{T}} 11^{\mathrm{T}}\end{array}$ \\
\hline M. boevrei $88365^{\mathrm{T}}$ & 41 & 1 & $<10^{-5}$ & $-b$ & - & $6.2 \times 10^{-5}$ \\
\hline M. bovis ATCC $10900^{\mathrm{T}}$ & $41-44.5$ & $<10^{-4}$ & 1 & & & $1.2 \times 10^{-4}$ \\
\hline M. lacunata A947 & $40-44$ & - & & 1 & & \\
\hline M. atlantae A1922 & $46.5-47.5$ & - & & & 1 & \\
\hline M. (B.) catarrhalis $\mathrm{Ne} 11^{\mathrm{T}}$ & $40-43$ & $<10^{-4}$ & & & & 1 \\
\hline N. elongata $6171 / 75$ & $53-54.7$ & - & & & & $1.2 \times 10^{-5}$ \\
\hline
\end{tabular}

"The data for strain $88365^{\mathrm{T}}$ are from this study; the data for other strains are from references $6,7,12$, and 28 .

b- transformants were not detected in semiquantitative transformation experiments. 
of DNA by using a Rediprime random priming labelling kit (Amersham International, Inc., Buckinghamshire, England) according to the manufacturer's recommendations.

(iii) Hybridization. Hybridization was performed by using a previously described protocol $(23,31)$. The sodium salt concentration of the prehybridization and hybridization fluids was $0.1 \mathrm{M}$. The hybridization results of the dot blot procedure were determined by overnight autoradiography (Hyperfilm MP; Amersham) and scintillation counting (Packard Instruments Co., Inc., Meriden, Conn.) of standard-cut pieces of the nitrocellulose filter obtained with a selfdesigned vacuum cutting device.

(iv) Quantitation of the dot blot hybridization reaction mixture. The mean of the counts per minute for the eight parallel determinations minus the control counts per minute obtained with salmon sperm DNA for each of the strains was determined. The mean counts per minute for the autologous strain minus the mean counts per minute for salmon sperm DNA was defined as a DNA homology ratio or RBR of $100 \%$. The mean RBR of each strain was calculated as follows: [(mean counts per minute for the strain - mean counts per minute for salmon sperm DNA)/mean counts per minute for the autologous reaction] $\times$ 100 . The $95 \%$ confidence interval of the sample mean of the RBRs was estimated for each experiment (data not shown).

rRNA gene restriction analysis (ribotyping). (i) DNA endonuclease digestion. Total DNA (5 to $7 \mu \mathrm{g}$ ) was cleaved with $15 \mathrm{U}$ of $\mathrm{HindIII}$ at $37^{\circ} \mathrm{C}$ for $4 \mathrm{~h}$. Digestion was performed with one-half of the enzyme for $2 \mathrm{~h}$, and then the othe half of the enzyme was added and the preparation was incubated for an additional $2 \mathrm{~h}$. HindIII was selected on the basis of the results of preliminary experiments in which this enzyme gave the best results in terms of complete digestion, as well as number and/or distribution of rRNA gene restriction patterns. The reaction was stopped by heating the reaction mixture at $65^{\circ} \mathrm{C}$ for 10 min before DNA restriction fragments were separated on a $0.8 \%(\mathrm{wt} / \mathrm{vol})$ agarose (type II medium EEO; Sigma Chemical Co., St. Louis, Mo.) gel by electrophoresis in $1 \times$ TAE buffer $(40 \mathrm{mM}$ Tris, $1 \mathrm{mM}$ EDTA [pH 8 , adjusted with glacial acetic acid]) for $16 \mathrm{~h}$ at $35 \mathrm{~V}$

(ii) Southern blots. DNA fragments were transferred to a neutral nylon membrane (Appligene, Illkirch, France) with a vacuum blotter apparatus (Trans-Vac TE 80; Hoefer Scientific Instruments, San Francisco, Calif.) at $5 \times 10^{3} \mathrm{~Pa}$ ove a period of approximately $45 \mathrm{~min}$, using $20 \times \mathrm{SSC}$ as the transfer solution. The transferred DNA fragments were immobilized on the membrane by UV crosslinking at $0.120 \mathrm{~J} / \mathrm{cm}^{2}$.

(iii) Prehybridization and hybridization. Prehybridization was carried out in $10 \mathrm{ml}$ of prehybridization buffer $(2 \times \mathrm{SCC}, 0.1 \%$ Ficoll, $0.1 \%$ polyvinylpyrrolidone, $0.1 \%$ glycine) containing $1 \mathrm{mg}$ of heat-denatured salmon sperm DNA per $\mathrm{ml}$ at $65^{\circ} \mathrm{C}$ for $2 \mathrm{~h}$, and this was followed by $16 \mathrm{~h}$ of hybridization at $65^{\circ} \mathrm{C}$ with 500 ng of heat-denatured acetylaminofluorene-labelled Escherichia coli $16+23 \mathrm{~S}$ rRNA (purchased from Eurogentec, Seraing, Belgium) per $\mathrm{ml}$ in $10 \mathrm{ml}$ of hybridization fluid $(2 \times \mathrm{SSC}, 0.02 \%$ Ficoll, $0.02 \%$ polyvinylpyrrolidone, $0.02 \%$ glycine, $25 \mathrm{mM} \mathrm{KH}_{2} \mathrm{PO}_{4}$ [pH 8.0], 2 mM EDTA, $0.5 \%$ SDS, $10 \%$ polyethylene glycol $6000,100 \mu \mathrm{g}$ of heat-denatured salmon sperm DNA per ml). Washing and detection of hybrids were performed as recommended by the manufacturer (Eurogentec).

(iv) DNA fragment size determination. The sizes of the rRNA gene restriction fragments were calculated from migration distances by using the computer program Taxotron, purchased from Institut Pasteur, Paris, France. The program also included a module for normalized schematic representation of rRNA gene restriction fragments.

Determination of the $\mathbf{G}+\mathbf{C}$ content of DNA. The overall base compositions of the DNAs of the new Moraxella strains were determined by high-performance liquid chromatography as described by Peyret et al. (26). DNA of $M$. bovis type strain ATCC 10900 was included in the study as a control. The DNA base composition of each strain was expressed as the moles percent of $(G+C)$ in the total bases, as determined by the following relationship: [(guanine + cytosine) $x$ $100] /$ (guanine + cytosine + adenine + thymine)

\section{RESULTS}

Genetic transformation. The results of the genetic transformation experiments are presented in Table 2. DNA from a streptomycin-resistant mutant of strain $88365^{\mathrm{T}}(\mathrm{T}=$ type strain) was used as the donor DNA representing the putative new Moraxella species.

Quantitative and semiquantitative genetic transformation assays performed with $M$. bovis ATCC $10900^{\mathrm{T}}, M$. lacunata A947, Moraxella atlantae A1922, and Moraxella (Branhamella) catarrhalis $\mathrm{Ne}^{\mathrm{T}} 1^{\mathrm{T}}$ as the recipients and strain $88365^{\mathrm{T}}$ DNA as the donor DNA gave ratios of interstrain transformation to intrastrain transformation of less than $5 \times 10^{-5}$ to $6.5 \times 10^{-5}$ (Table 2). Similar results were obtained in semiquantitative transformation experiments in which strain $88365^{\mathrm{T}}$ was the
TABLE 3. RBRs in DNA-DNA hybridization experiments

\begin{tabular}{|c|c|c|}
\hline \multirow{2}{*}{ Filter DNA source } & \multicolumn{2}{|c|}{$\begin{array}{l}\text { Mean RBR with }{ }^{32} \mathrm{P} \text {-labelled } \\
\text { DNA from: }\end{array}$} \\
\hline & $\begin{array}{c}\text { M. boevrei } \\
88365^{\mathrm{T}}\end{array}$ & $\begin{array}{c}\text { M. bovis } \\
\text { ATCC } 10900^{\mathrm{T}}\end{array}$ \\
\hline \multicolumn{3}{|l|}{ Moraxella boevrei sp. nov. strains } \\
\hline $88365^{\mathrm{T}}$ & 100 & 10 \\
\hline $88363 \mathrm{~A}$ & 95 & 12 \\
\hline $88363 \mathrm{~B}$ & 78 & $\mathrm{ND}^{a}$ \\
\hline $88364 \mathrm{~A}$ & 58 & \\
\hline 88366 & 99 & \\
\hline 88369 & $>100$ & \\
\hline \multicolumn{3}{|l|}{ M. caprae strains } \\
\hline NCTC $12877^{\mathrm{T}}\left(=\right.$ CCUG $\left.33297^{\mathrm{T}}\right)$ & 11 & 42 \\
\hline 88100 & 7 & \\
\hline 88103 & 7 & \\
\hline 88104 & 7 & \\
\hline 88105 & 5 & \\
\hline \multicolumn{3}{|l|}{ M. bovis strains } \\
\hline ATCC $10900^{\mathrm{T}}$ & $10-14^{b}$ & 100 \\
\hline 9 & 23 & \\
\hline ATCC 17947 & 17 & \\
\hline NCTC $11012^{\mathrm{T}}$ (M. equi) & 18 & 47 \\
\hline \multicolumn{3}{|l|}{ M. lacunata strains } \\
\hline ATCC $17967^{\mathrm{T}}$ & 11 & \\
\hline A947 & 4 & \\
\hline 50136 & 7 & \\
\hline M. nonliquefaciens ATCC $19975^{\mathrm{T}}$ & $12-23^{b}$ & \\
\hline M. osloensis 5873 & 6 & \\
\hline M. atlantae CIP $8225^{\mathrm{T}}$ & 4 & \\
\hline M. phenylpyruvica CIP $8227^{\mathrm{T}}$ & 5 & \\
\hline M. lincolnii CCUG $9505^{\mathrm{T}}$ & 1 & \\
\hline Moraxella (Branhamella) ovis $199 / 55^{\mathrm{T}}$ & 14 & \\
\hline M. (B.) catarhalis $\mathrm{Ne} 11^{\mathrm{T}}$ & 3 & ND \\
\hline \multicolumn{3}{|l|}{ Other gram-negative species ${ }^{c}$} \\
\hline Kingella kingae & $<1$ & \\
\hline$K$. denitrificans & $<1$ & \\
\hline Neisseria elongata & $<1$ & \\
\hline N. weaveri & $<1$ & \\
\hline Oligella urethralis & $<1$ & \\
\hline Eikenella corrodens & $<1$ & \\
\hline Psychrobacter immobilis & 3 & \\
\hline Haemophilus aphrophilus & 3 & \\
\hline H. paraphrophilus & 7 & \\
\hline Pasteurella multocida & $<1$ & \\
\hline P. haemolytica & 8 & \\
\hline Escherichia coli & $<1$ & \\
\hline
\end{tabular}

${ }^{a} \mathrm{ND}$, not determined.

${ }^{b}$ Range of values from three sets of experiments.

'See Table 1 for the designations of the strains used.

recipient. When $M .(B)$ catarrhalis $\mathrm{Ne}^{\mathrm{T}} 1^{\mathrm{T}}$ was used as the recipient, the ratio of interspecies transformation to intrastrain transformation with strain $88365^{\mathrm{T}}$ as the donor was significantly higher than ratio obtained with Neisseria elongata $6171 / 75\left(6.5 \times 10^{-5}\right.$, compared with $\left.1.2 \times 10^{-5}\right)$.

DNA-DNA hybridization. The results of the DNA-DNA hybridization experiments are shown in Table 3. DNA-DNA dot blot hybridization analysis showed that DNAs from the six new Moraxella strains displayed mean RBRs ranging from 58 to $100 \%$ (most values were more than $78 \%$ ) when DNA from putative new Moraxella sp. strain $88365^{\mathrm{T}}$ was used as the probe. DNA from strain $88365^{\mathrm{T}}$ was chosen as a total genomic probe that was representative of the new group to test the affinity of this group to different Moraxella species and other fastidious gram-negative bacterial species included in the study (Table 3 ). The new strains were clearly distinguished from previously 


M. boevrei 88365
M. boevrei 88363 B
M. boevrei 88363 A
M. boevrei 88364 A
M. boevrei 88366
M. boevrei 88369
M. caprae $8897 \mathrm{~T}$
M. bovis ATCC $10900^{\mathrm{T}}$
M. bovis 17948
M. bovis PG 501
M. bovis PG 500
M. nonliquefaciens ATCC $19975^{\mathrm{T}}$
M. lacunata ATCC $17967^{\mathrm{T}}$
M. lacunata 50136
M. (B) ovis $199 / 55^{\mathrm{T}}$
M. (B) caviae ATCC $14659^{\mathrm{T}}$
M. (B) cuniculi ATCC $14688^{\mathrm{T}}$
M. osloensis CIP $6835^{\mathrm{T}}$
M. atlantae CIP $8225^{\mathrm{T}}$
M. phenylpyrouvica CIP $8227^{\mathrm{T}}$
O. urethralis ATCC $17960^{\mathrm{T}}$

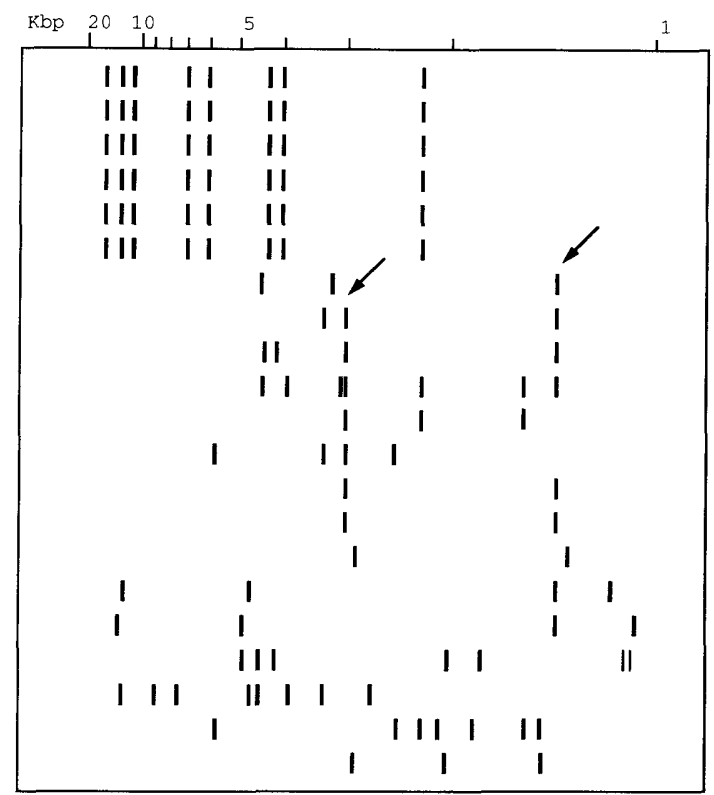

FIG. 1. Normalized schematic representation of the rRNA gene restriction fragments obtained after digestion of total DNA with HindIII and hybridization with acetylaminofluorene-labelled $16+23 \mathrm{~S}$ RNA from $E$. coli. The arrows indicate common bands found in most classical moraxellae.

described Moraxella species and other gram-negative bacterial species included in the study by their RBRs in hybridization experiments (Table 3). However, higher RBRs were obtained with DNAs from species belonging to the genus Moraxella than with DNAs from other gram-negative species; in particular, high RBRs were obtained with DNAs from strains belonging to $M$. bovis, $M$. nonliquefaciens, and Moraxella ovis, with which RBRs as high as 14 and $23 \%$ were obtained when DNA of strain $88365^{\mathrm{T}}$ was used as the probe and $M$. ovis $199 / 55^{\mathrm{T}}$ and $M$. bovis 9 or $M$. nonliquefaciens ATCC $19975^{\mathrm{T}}$ DNAs were used as the filterbound DNAs, respectively.

rRNA gene restriction patterns. The results of the rRNA gene restriction pattern analysis showed that the new goat strains were similar to each other and different from all other Moraxella species included in the study. The HindIII rRNA gene restriction fragments included an approximately $3.0-\mathrm{kb}$ band found in most species belonging to the classical moraxellae, including the two clinical isolates, M. bovis PG 500 and PG 501. This DNA fragment was not found in the recently described organism $M$. caprae (Fig. 1). An additional band at approximately $1.3 \mathrm{~kb}$ was sometimes found in the same species (including $M$. caprae), as well as $M$. bovis, Moraxella cuniculi, and Moraxella caviae. Moraxella osloensis, M. atlantae, and Moraxella phenylpyruvica each displayed a unique pattern.

DNA base composition. The results of the determination of the $\mathrm{G}+\mathrm{C}$ contents of DNAs are presented in Table 2. The $\mathrm{G}+\mathrm{C}$ contents of the DNAs of the new goat strains were similar, ranging from 41 to $41.5 \mathrm{~mol} \%$. The $\mathrm{G}+\mathrm{C}$ content of the DNA of $M$. bovis ATCC $10900^{\mathrm{T}}$ included in the study was $40 \mathrm{~mol} \%$.

\section{DISCUSSION}

The six new bacterial strains were assigned to the genus Moraxella on the basis of their Gram reaction, cellular morphology, absence of motility, positive oxidase reaction, and other reactions in a panel of conventional biochemical and hydrolytic enzymatic tests and were referred as to group 1 in previous studies $(21,22)$. Because they had most of the properties of $M$. bovis except nitrate reduction, we originally considered these goat isolates members of $M$. bovis. However, results obtained from SDS-polyacrylamide gel electrophoresis of whole-cell proteins showed that the group of goat isolates was very homogeneous and produced a protein profile different from the profiles produced by typical strains of $M$. bovis, $M$. lacunata, and $M$. nonliquefaciens. Nevertheless, $M$. bovis was their closest neighbor (22). Therefore, it was important to define the genetic affinities of these isolates (formerly group 1) to all members of the genus Moraxella, including taxa belonging to the classical moraxellae. Genetic transformation in which the high-level streptomycin or spectinomycin resistance marker or nutritional mutants have been used as a specific tool in Moraxella species differentiation has been exploited extensively by Bøvre (4), Bøvre and Hagen (7), Henriksen and Bøvre (11), Juni et al. (18), and other workers (12, 32). The results of experiments in which DNA-DNA dot blot hybridization was used with total genomic and pilin-specific PCR probes, as well as the results of multilocus enzyme electrophoresis, correlate well with the results of genetic transformation analyses $(29,31)$. The results of the present study, in addition to the results of previous protein and qualitative genetic transformation analyses $(21,22)$, clearly indicate that the new isolates constitute a new cluster of strains that has affinity for the genus Moraxella, but is different from $M$. bovis in cattle and $M$. nonliquefaciens in humans. DNAs from the new goat strains displayed high RBRs with each other ( $\geq 58 \%$ ) but distinctly lower RBRs with DNAs of all other species investigated. However, the RBRs were somewhat higher with members of the genus Moraxella than with other gram-negative bacteria included in the present study. The ratio of interstrain transformation to intrastrain transformation of DNA from streptomycin-resistant strain $88365^{\mathrm{T}}$ when $M$. catarrhalis $\mathrm{Ne} 11^{\mathrm{T}}$ was the recipient is also in the range found for the other Moraxella species. The base compositions of the DNAs of the new strains match the base compositions determined for the 
TABLE 4. Phenotypic characteristics of M. boevrei and other Moraxella species ${ }^{a}$

\begin{tabular}{|c|c|c|c|c|c|c|c|c|c|c|c|c|c|c|}
\hline Characteristic & M. boevrei & M. bovis & M. caprae & M. lacunata & $\begin{array}{l}\text { M. nonlique- } \\
\text { faciens }\end{array}$ & M. osloensis & M. lincolnii & M. atlantae & $\begin{array}{l}\text { M. phenyl- } \\
\text { pyruvica }\end{array}$ & M. (B.) ovis & $\begin{array}{l}\text { M. }(B .) \\
\text { caviae }\end{array}$ & $\begin{array}{l}\text { M. (B.) } \\
\text { cuniculi }\end{array}$ & M. canis & $\begin{array}{l}\text { M. catar- } \\
\text { rhalis }\end{array}$ \\
\hline Morphology ${ }^{b}$ & SR & $\mathrm{R}$ & $\mathrm{R}$ & $\mathrm{R}$ & $\mathrm{R}$ & $\mathrm{R}$ & $\mathrm{C}, \mathrm{R}$ & $\mathrm{R}$ & $\mathrm{R}$ & $\mathrm{C}$ & $\mathrm{C}$ & $\mathrm{C}$ & $\mathrm{C}$ & $\mathrm{C}$ \\
\hline Motility & $-^{c}$ & - & - & - & - & - & - & - & - & - & - & - & - & - \\
\hline Catalase activity & + & $(+)$ & + & + & + & + & + & + & + & + & + & + & + & + \\
\hline Oxidase activity & + & + & + & + & + & + & + & + & + & + & + & + & + & + \\
\hline Growth on MacConkey agar & - & - & - & - & - & $\mathrm{v}$ & NT & + & NT & - & - & - & - & - \\
\hline Acids produced from glucose & - & - & - & - & - & - & - & - & - & - & - & - & - & - \\
\hline Growth on minimal medium ${ }^{d}$ & - & - & - & - & - & + & NT & - & - & - & - & - & $(+)$ & - \\
\hline Hemolysis & + & $+^{e}$ & + & - & - & - & - & - & - & $(+)$ & w & - & + & - \\
\hline Nitrate reduction & + & $(-)$ & + & + & + & $(-)$ & - & - & $(+)$ & + & + & - & + & $(+)$ \\
\hline Liquefaction of gelatin & + & + & - & + & - & - & - & - & - & - & - & - & - & - \\
\hline DNase activity & - & - & - & - & - & - & - & - & - & $(-)$ & $(-)$ & - & $(+)$ & + \\
\hline Proteolysis on Löffler slants & + & + & - & + & - & - & - & - & - & - & - & - & - & - \\
\hline Indole & - & - & - & - & - & - & NT & - & - & - & - & - & - & - \\
\hline Phenylalanine deaminase activity & - & - & - & - & - & - & - & NT & + & - & - & - & - & - \\
\hline Hydrolysis of Tween 80 & + & + & + & + & - & - & - & - & NT & - & - & - & - & - \\
\hline Alkaline phosphatase activity & - & - & - & + & - & + & - & + & NT & + & + & + & + & + \\
\hline Esterase activity & + & + & - & + & + & + & + & + & NT & + & + & + & + & + \\
\hline Acid phosphatase activity & - & w & - & w & - & + & - & + & NT & - & - & $\mathrm{w}$ & - & - \\
\hline $\mathrm{G}+\mathrm{C}$ content $(\mathrm{mol} \%)$ & $41-41.5$ & $41-44.5$ & $40-41.5$ & $40-44.5$ & $40-44$ & $43-46$ & 44 & $46.5-47.5$ & $42.5-43.5$ & $44.5-46.5$ & $44.5-47.5$ & 44.5 & $45.5-49.6$ & $40-43$ \\
\hline
\end{tabular}

${ }^{a}$ Data from this study and references $6,7,16,22,23$, and 34

${ }^{b} \mathrm{C}$, coccus; R, rod; SR, short rod.

$c-$, negative reaction; + , positive reaction; w, weak reaction; $(+)$, most strains are positive; $(-)$, most strains are negative; NT, not tested.

${ }^{d}$ Minimal medium containing ammonium and acetate.

e $M$. equ strains which belong to the species M. bovis do not exhibit hemolysis. 
genus Moraxella $(6,7,9,16,28,34)$. The rRNA gene restriction patterns also indicated that the new cluster should be separated from the other Moraxella species investigated. The presence of at least two common bands in the species included in the classical moraxellae could be useful for Moraxella differentiation, particularly for distinguishing the classical moraxellae from other Moraxella species. However, the number of strains investigated in this study is not sufficient to create a general scheme for distinguishing the members of the genus Moraxella.

Based on the results presented above, we propose that the goat strains belong to a new species in the genus Moraxella, Moraxella boevrei sp. nov. The number of Moraxella species has increased in recent years with the proposals of several new Moraxella species, including Moraxella lincolnii (34), Moraxella canis, (16), and $M$. caprae (23), which shows how widespread strains of the genus Moraxella are in mammals. The usual keys used to identify these organisms in clinical laboratories are not sufficient for differentiating most Moraxella species and should therefore be combined with other methods, such as genetic transformation or rapid total DNA-DNA hybridization assays. For example, although genetic analysis reveals a clear-cut distinction between $M$. bovis and $M$. boevrei, these two species have the same features (except nitrate reduction) on the basis of the phenotypic criteria listed in Table 4.

Description of Moraxella boevrei sp. nov. Moraxella boevrei (boev're.i, L. gen. n. boevrei, of Bøvre, in honor of Kjell Bøvre, a Norwegian microbiologist, in recognition of his many contributions to the field of Moraxella and Neisseria identification and taxonomy [4, 7, 23, 29, 32]). Cells are gram-negative thin rods to coccus-like structures and have a tendency to occur as diplobacilli or in short chains. They are nonmotile, aerobic, and mesophilic. Colonies are grey-white, rough, and small (diameter after $48 \mathrm{~h}, 0.5 \mathrm{~mm}$ ) and are surrounded by a wide area of hemolysis. Growth occurs in an aerobic atmosphere (preferably containing $5 \% \mathrm{CO}_{2}$ ) on $5 \%$ sheep or human blood agar plates or chocolate agar plates. Growth does not occur or occurs weakly on nutrient agar. The oxidase and catalase reactions are strongly positive. All strains hydrolyze Tween 80 and reduce nitrate. No acid is produced from carbohydrates. All strains are proteolytic (Loeffler slants and gelatin positive). Indole and urease reactions are negative. The only conventional characteristic that distinguishes $M$. boevrei from $M$. bovis is the reduction of nitrate. Otherwise all other conventional and hydrolytic enzymes of $M$. boevrei and $M$. bovis are exactly the same. The $\mathrm{G}+\mathrm{C}$ content ranges from 41 to $41.5 \mathrm{~mol} \%$ (Table 4). The clinical significance is uncertain. Strain 88365 $(=$ ATCC $700022=$ CCUG $35435=$ NCTC $12925=$ CIP 104716), which was isolated in 1988 from the nasal cavity of a healthy goat, is the type strain.

\section{ACKNOWLEDGMENTS}

We are indebted to Eva Løvstad and Hélène Meugnier for excellent technical assistance.

This work was supported by a grant from the Anders Jahres Foundation to T.T. and by a Federation of European Microbiological Societies fellowship to A.K.

\section{REFERENCES}

1. Andersen, B. M., A. G. Steigerwalt, S. P. O'Connor, D. G. Hollis, R. S. Weyant, R. E. Weaver, and D. J. Brenner. 1993. Neisseria weaveri sp. nov., formerly CDC group M-5, a gram-negative bacterium associated with dog bite wounds. J. Clin. Microbiol. 31:2456-2466.

2. Barber, D. M. L. 1985. Bacterial population of slaughter cattle. Vet. Rec. 115:169-170.

3. Barber, D. M. L., and G. E. Jones. 1988. An attempt to induce clinical infectious keratoconjunctivitis in calves with naturally occurring Moraxella bovis infection. Vet. Rec. 122:210-211.
4. Bøvre, K. 1965. Studies on transformation in Moraxella and organisms assumed to be related to Moraxella. 3. Quantitative streptomycin resistance transformation between Moraxella bovis and Moraxella nonliquefaciens strains. Acta Pathol. Microbiol. Scand. 63:42-50.

5. Bøvre, K. 1965. Studies on transformation in Moraxella and organisms assumed to be related to Moraxella. 5. Streptomycin resistance transformation between serum-liquefying, nonhaemolytic moraxellae, Moraxella bovis and Moraxella nonliquefaciens. Acta Pathol. Microbiol. Scand. 65:435-449.

6. Bøvre, K. 1984. Genus II. Moraxella Lwoff 1939, 173 emend. Henriksen and Bøvre 1968, 391 ${ }^{\mathrm{AL}}$, p. 296-303. In N. R. Krieg and J. B. Holt (ed.), Bergey's manual of systematic bacteriology, vol. 1. The Williams \& Wilkins Co., Baltimore, Md.

7. Bøvre, K., and N. Hagen. 1980. The family Neisseriaceae: rod-shaped species of the genera Moraxella, Acinetobacter, Kingella, and Neisseria, and the Branhamella group of cocci, p. 1506-1529. In M. P. Starr et al. (ed.), The prokaryotes. A handbook on habitats, isolation, and identification of bacteria, vol. II. Springer-Verlag, Berlin, Germany.

8. Cabassi, E., F. Cattabiani, F. Brindani, and E. Freschi. 1975. La flora bactterica della mucosa nasale del cavallo. Nota I. Batteri Gram-negativi. Folia Vet. Lat. 5:55-85.

9. Catlin, B. W. 1991. Branhamaceae fam. nov,, a new proposed family to accommodate the genera Branhamella and Moraxella. Int. J. Syst. Bacteriol. 41:320-323.

10. Gerhardt, R. R., J. W. Allen, W. H. Greene, and P. C. Smith. 1983. The role of face flies in an episode of infectious bovine conjunctivitis. J. Am. Vet. Med. Assoc. 180:156-159.

11. Henriksen, S. D., and K. Bøvre. 1968. The taxonomy of the genera Moraxella and Neisseria. J. Gen. Microbiol. 51:387-392.

12. Hoke, C., and N. A. Vedros. 1982. Taxonomy of the Neisseriaceae: deoxyribonucleic acid base composition, interspecific transformation, and deoxyribonucleic acid hybridization. Int. J. Syst. Bacteriol. 32:57-66.

13. Hoquet, F., R. Higgins, P. Lessard, A. Vrins, and M. Marcoux. 1985. Comparison of bacterial and fungal flora in the pharynx of normal horses and horses affected with pharyngitis. Can. Vet. J. 26:342-346.

14. Hughes, D. E., and G. W. Pugh. 1970. Isolation and description of a Moraxella from horses with conjunctivitis. Am. J. Vet. Res. 31:457-459.

15. Huntington, P. J., P. J. Coloe, J. D. Bryden, and F. MacDonald. 1987. Isolation of a Moraxella sp. from horse with conjunctivitis. Aust. Vet. J. 64:118-119.

16. Jannes, G., M. Vaneechoutte, M. Lannoo, M. Gillis, M. Vancanneyt, P. Vandamme, G. Verschraegen, H. Van Heuverswyn, and R. Rossau. 1993. Polyphasic taxonomy leading to the proposal of Moraxella canis sp. nov. for Moraxella catarrhalis-like strains. Int. J. Syst. Bacteriol. 43:438-449.

17. Juni, E. 1974. Simple genetic transformation assay for rapid diagnosis of Moraxella osloensis, Appl. Microbiol. 27:16-24.

18. Juni, E., G. A. Heym, M. J. Maurer, and M. L. Miller. 1987. Combined genetic transformation and nutritional assay for identification of Moraxella nonliquefaciens. J. Clin. Microbiol. 25:1691-1694.

19. Juni, E., G. A. Heym, and R. D. Newcomb. 1988. Identification of Moraxella bovis by qualitative genetic transformation and nutritional assays. Appl. Environ. Microbiol. 54:1304-1306.

20. Kodjo, A., A. Dorier, C. Lerondelle, and Y. Richard. 1994. Isolation of a new biovar of Moraxella bovis from healthy caprine nasal swabs. Small Ruminant Res. 15:87-95.

21. Kodjo, A., P. Exbrayat, and Y. Richard. 1994. Identification of Moraxella bovis and related species from calves with IBK and goats by qualitative genetic transformation assay. J. Vet. Med. Ser. B 41:336-343.

22. Kodjo, A., A. Moussa, E. Borges, and Y. Richard. 1993. Identification of Moraxella-like bacteria isolated from caprine and ovine nasal flora. J. Vet. Med. Ser. B 40:97-104.

23. Kodjo, A., T. Tønjum, Y. Richard, and K. Bøvre. 1995. Moraxella caprae $\mathrm{sp}$ nov., a new member of the classical moraxellae. Int. J. Syst. Bacteriol. 45:467-471.

24. Marmur, J. G. 1961. A procedure for the isolation of deoxyribonucleic acid from micro-organisms. J. Mol. Biol. 3:208-218.

25. Pande, P., and P. C. Sekariah. 1960. A preliminary note on the isolation of Moraxella caprae nov. sp. from an outbreak of infectious keratoconjunctivitis in goats. Curr. Sci. 29:276-277.

26. Peyret, M., J. Freney, H. Meugnier, and J. Fleurette. 1989. Determination of $\mathrm{G}+\mathrm{C}$ content using high-performance liquid chromatography for the identification of staphylococci and micrococci. Res. Microbiol. 140:467-475.

27. Ringvold, A., E. Vik, and L. S. Bevanger. 1985. Moraxella lacunata isolated from epidemic conjunctivitis among teenaged females. Acta Ophthalmol. 63:427-431.

28. Rossau, R., A. Vanlandschoot, M. Gillis, and J. De Ley. 1991. Taxonomy of Moraxellaceae fam. nov., a new bacterial family to accommodate the genera Moraxella, Acinetobacter, and Psychrobacter and related organisms. Int. J. Syst. Bacteriol. 41:310-319.

29. Tønjum, T., G. Bukholm, and K. Bøvre. 1989. Differentiation of some species of Neisseriaceae and other bacterial groups by DNA-DNA hybridization. Acta Pathol. Microbiol. Immunol. Scand. 97:395-405.

30. Tønjum, T., G. Bukholm, and K. Bøvre. 1990. Identification of Haemophilus 
aphrophilus and Actinobacillus actinomycetemcomitans by DNA-DNA hybridization and genetic transformation. J. Clin. Microbiol. 28:1994-1998.

31. Tønjum, T., D. A. Caugant, and K. Bøvre. 1992. Differentiation of Moraxella nonliquefaciens, $M$. lacunata, and $M$. bovis by using multilocus enzyme electrophoresis and hybridization with pilin-specific DNA probes. J. Clin. Microbiol. 30:3099-3107.

32. Tønjum, T., N. Hagen, and K. Bøvre. 1985. Identification of Eikenella corrodens and Cardiobacterium hominis by genetic transformation. Acta Pathol.
Microbiol. Immunol. Scand. Sect. B 93:386-394.

33. Travicek, M., T. Dravecky, and J. Balascak. 1982. Isolation of Chlamydia psittaci and Moraxella bovis from infectious keratoconjunctivitis in lambs. Vet. Med. (Prague) 27:491-496.

34. Vandamme, P., M. Gillis, M. Vancanneyt, B. Hoste, K. Kersters, and E. Falsen. 1993. Moraxella lincolnii sp. nov. isolated from the human respiratory tract, and reevaluation of the taxonomic position of Moraxella osloensis. Int. J. Syst. Bacteriol. 43:474-481. 